日本鳥類標識協会誌 $19(1): 8-26,2006$

越後平野におけるガン・ハクチョウ類の採食水田の分布

渡辺朝一

\title{
Distribution of Rice Paddy Feeding Sites for Geese and Swans on the Echigo Plain, Niigata Prefecture, Central Honshu, Japan
}

\section{Tomokazu WATANABE}

新潟県中央部に広がる越後平野一帯は, 宮城平野と並ぶ月本列島でも最大級のガン・ハクチョウ類 の越冬地である. 越後平野一带は, 信濃川, 阿賀野川の二大河川や, 後背湿地の残仔潟沼（鳥屋野潟,

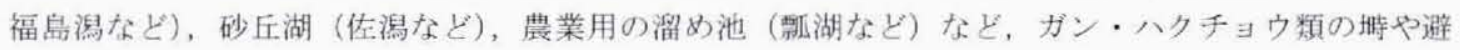
難場所となる開水面に恵まれている。それだけでなく, 越後平野は全国有数の款倉地带であり, 広大 な水田地帯が広がっている。このように, 越後平野一帯は, 開水面だけでなく, 周辺に採食の場（千 葉ら 1993, 本田 2001, 渡辺 2003）である広大な水田地带を搉しており, ガン・八クチョウ類の越冬

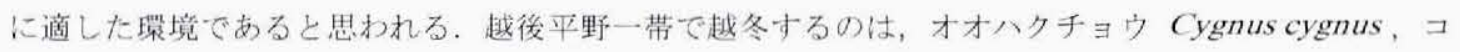
八クチョウ C.columbianus, マガン Anser albifrons, ヒシクイ A. fabalis の 4種である. 1990 年 頃から，特にコハクチョウの増加傾向が著しい（新潟県野鳥爱謢会研究部 1993）.

カンン・八クチョウ類を含むカモ科鳥類の個体数に関しては, 1969年から環境省が全国の都道府県に 依頼し，舞年調査が行なわれている。この調査は，ガン・カモ・八クチョウ類の保護と生息地に関す る基磁資料を得るために実施されているものであり, 越後平野一帯でも, 潟沿や二大河川などで行な われており,この調查結果は貴重な資料となっている(千葉 1985など).しかし, 越後平野一带では, ガン・八クチョウ類は, 内水面だけでなく周囲の水田にも積極的に飛来していることが見ら机ている. したがって, ガン・八クチョウ類の生態解明には, 内水面における個体数把握だけでなく, 彼らがど の場所の水田を利用しているのか明らかにする必要がある。これらがン・ハクチョウ類が利用する水 田に関しては, 過去に幾つかの発表もある。ヒシクイに関しては, 千葉ら（1993）が, その採食水田 を福島潟周辺の大縮尺の地図上に示した。コハクチョウに関しては, 本田 (2001) が，1979年〜1984 年, 1990年〜1991年の記録を，小維尺の地困上に示している。しかし、これらのガン・ハクチョウ類 各種の採食水田の記録は, 内水面で行なわれているような, 同一条件での記録ではない, 筆者は, 越 後平野一带に越冬するガン・八クチョウ類の採食水田を明確に把握するためには, 採食水田の地域ご

キーワード：マガン, オオヒシクイ, オオ八クチョウ, コハクチョウ, 越後平野, 採食水田.

Key Words: White-fronted Goose, Middendorf's Bean Goose, Whooper Swan, Bewick's Swan, Echigo

Plain, Rice Paddy Feeding Sites. 
との詳細な記録と，越後平野一帯の全体を俯瞰した記録がそれぞれ必要であると考え，1992年頃から 1994 年にかけて,ガン・ハクチョウ類の採食水田の調査を行なってきた。更に1994年12月から1995年 1月にかけては，未踏查であった各地の水田地带を踏查し，ガン・八クチョウ類の採食地を明らかに できたので，その結果を，地域ごとの詳細な地図と，越後平野全域を俯瞰できる小縮尺の地図の，二 種類の地図上に示した上で報告する。なお，越後平野一带に渡来越冬するヒシクイは，曲種才オヒ シクイ A. f. middendorffii であるとされており（下葉ら 1993），以下の筆者の調查でも，確諗された のはすべてオオヒシクイであった。オオヒシクイと, 日本列島では主に宮城平野に渡来越冬する亜種 ヒシクイ A.f serrirostris は，生態的に異なるとも言われており，種ヒシクイと曲種ヒシクイは混同 されないように，本報告では亜種名であるオオヒシタイを用いて記録した。

\section{調査地および調査方法}

越後平野は, 信濃川・阿賀野川の二大河川によって形成された沖積平野である (坂井 1991)。この 平野には, 微高地として扇状地, 自然堤防, 海岸砂丘が分布し, 主に集落が立地している. 後背湿地 は地形が四地をなしており，現在は，ほとんどが農道・排水路が整備された大规模な乾田となってい る. 越後平野の特徽として, 後背湿地の面積が広いこと, 洪積台地や扇状地の面積が他の平野と比較 して狭いことがあげられる，現在は水田となっている後背湿地は，周囲を集落となっている自然堤防 に囲まれ，中央には潟沼があった。これらの潟沼は，鳥屋野潟，福島潟などを除き，ほとんどが干拓 されてしまったが，現在も標高 $0 \mathrm{~m}$ 地帯として広く残っている，起伏が少なく，帯状に連なる集落に 囲まれた水田地带が広く展開している椂相が, 越後雨野独特の特徵的な景観である. 越後平野で越冬 するガン・八クチョウ類は, 潟沼や二大河川を煋や避難地とし, 周辺の水田地带を含めて行動圈とし ているものと䒓えられる。調査は, 水田地带を横切る農道を自動車で走行し, ガン・八クチョウ類の 存在の有無を確認した.

越後平野一帯は，代表的な裏日本型気候で，冬季の降水量が多い，特に年が明けてからは根雪にな ることもあり，そのような場合ガン・八クチョウ類は侍や採食地を移動させている可能性も高い.今 回の調查では，雪がガン・八クチョウ類の採食地選択に影響を及ぼしていないと思われる時期の記録 を使用した。また， 2 月中旬以降は，春の渡りが始まり，そのため越冬期前半とはかなり採食地の分布 も変わってくるので, この時期の記録も，原則として除外した。すなわち，冠雪と春の渡りがガン. 八クチョウ類の採食地選択に影響を及ぼさないと考えられる，越冬期前半の11月〜 1月上句にかけて の記録を中心に使用した，用いた記録は1992年から1995年にかけてのものである。ガン・八クチョウ 類の採食水田であると，知られた場所の記録は文章に記すだけにとどめ，知られていないと考えられ た場所での記録は，文章中に観察日と観察した個体数を記録した。

新潟県でも，2004年から2005年にかけて多くの市町村合併が行なわれ，調査当時と市町村名が変わ った場所が多い、本報告では, 地名を多く表記する関係上，場所を特定しやすくするために，調查当 時の古い市町村名を用いて記録した。また，1994年に一部開通した盤越自動車道や，2002年に一部開 通した日本海東北自動車道は，開通前の記録老多く用いた関係上，地図上に記さなかった。

また, 調査当時の越後平野一带におけるガン・八クチョウ類の渡来状況を示すため, 新潟県野鳥愛 
護会による1993年から1995年の各 1月15日に実施されたカモ科鳥類の生息状況調查（新潟県野鳥愛護 会研究部 1993，1994，1995）からマガン，ヒシクイ，オオ八クチョウ，コハクチョウの記録を拔き出 し, 付表によとめた.

\section{結 果}

1. 地域別の採食水田分布状況

1) 村上・岩船地区（荒川以北，図 1)

荒川以北では, 新保の大池が, 唯一のハクチョウ類の埘となっている．1994年12月3日に荒川以北 の水田地带を調查したが，神林村飯㧫集落付近の水田にてコハクチョウ 45 羽（成鳥 44 , 幼鳥 1 ）を観 察したのみであった。

2)胎内川〜荒川間 (図 1)

この付近にガン・ハクチョウが時とする潟沼は存在しない. 水田地带に掠いてもガン・ハクチョウ 類は観察できなかった。

3) 中条・加治川地区 (胎内川 加治川間, 図 1, 図 2)

この地区にも知られている埘はない，距雗的に最も近いと考えられる侍は，新発出市の升潟である. 中条町, 加治川村でも, 胎内川以北と同様に, 北部の水田ではコハクチョウは全く観察されなかった. 加治川に近くなって，金塚駅に近い戸野港集落付近の水田で，1995年1月3日にコハクチョウ8 羽 （成鳥 7, 幼鳥 1) を観察した。同じく加治駅に近い下今泉集落付近の水田で, 同日コハクチョウ79 羽を観察した。紫雲寺町高山寺集落付近の水田ではオオヒシクイが見られた。この場所は下葉ら(1992) の記録にもない，従来知られていなかったオオヒシクイの採食水田である (1993年2月6日 67 羽, 11月 27 日 50 羽以上など)。この水田地帯は1992年から1993年にかけてのシーズンはコ八クチョウも採食地 として使用していたが，翌1993年から1994年にかけてのシーズンには見られなからた。

4) 新発田市街地上り山側（図2）

新発田の市街地の奥に升潟があり、コハクチョウの挂となっている. 升潟の前面は水田地带である が，ガン・八クチョウが降りているのを見たことがない，

加治川とその支流である坂井川，姫田川沿いに水田が広がっており，宫古木集落付近の水田で1995 年 1 月 3 日にコハクチョウ 3 羽（成鳥 2 , 幼鳥 1) を観察した。その下流にあたる米倉集落付近，大 友集落付近ではガン・ハクチョウ類は観察されなかった。坂井川と姫田川に挟まれた下中江集落付近 の水田で1994年12月30日に1家族群を観察した。また，加治川と櫛形山脈に連なる丘陵に挟まれたみ 切集落付近で 1 家族群を観察した.

5) 新発田市街地より北側（加治川〜新潟東港，図 2)

弁天潟や福島潟に近く、コハクチョウの数は多い, 新発田市街地の北側, 中谷内集落から諏訪山, 大夫付近の水田にはコハクチョウは常に見られる，運転免許センターの東側にあたる蓮潟新田集落付 近でも1994年12月30日に成鳥 2 羽老確認した。新新バイバスを挟んだ三賀付近の水田では，ガン・八 クチョウ類を見たことはない.

オオヒシクイの時である福島潟からはそれほど遠くないが，オオヒシクイをこの周辺で見たことは 


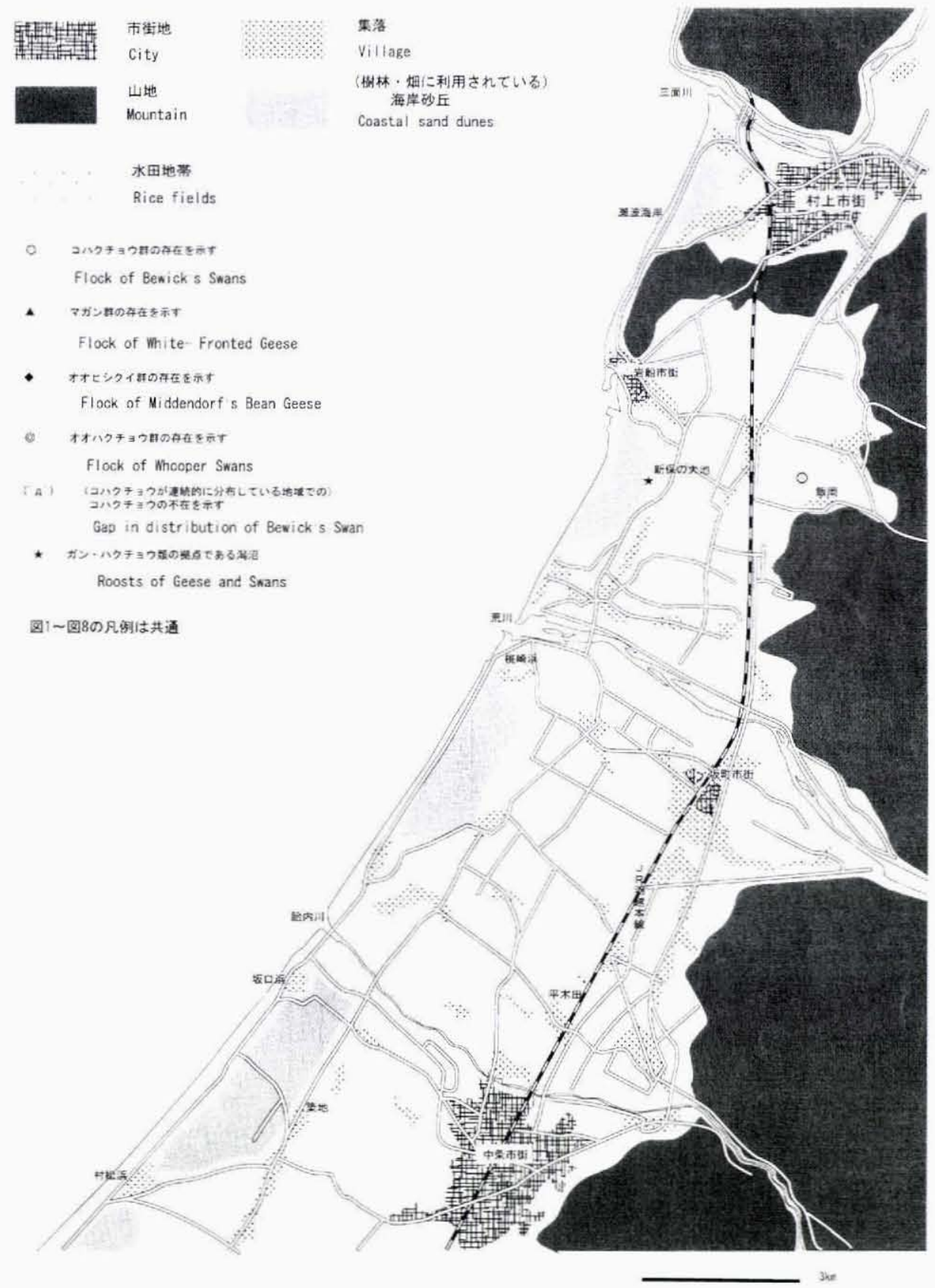

図 1. ガン・ハクチョウ類の採食水田 (村上〜中条).

Fig. 1. Rice paddy feeding sites in Iwafune Area. 


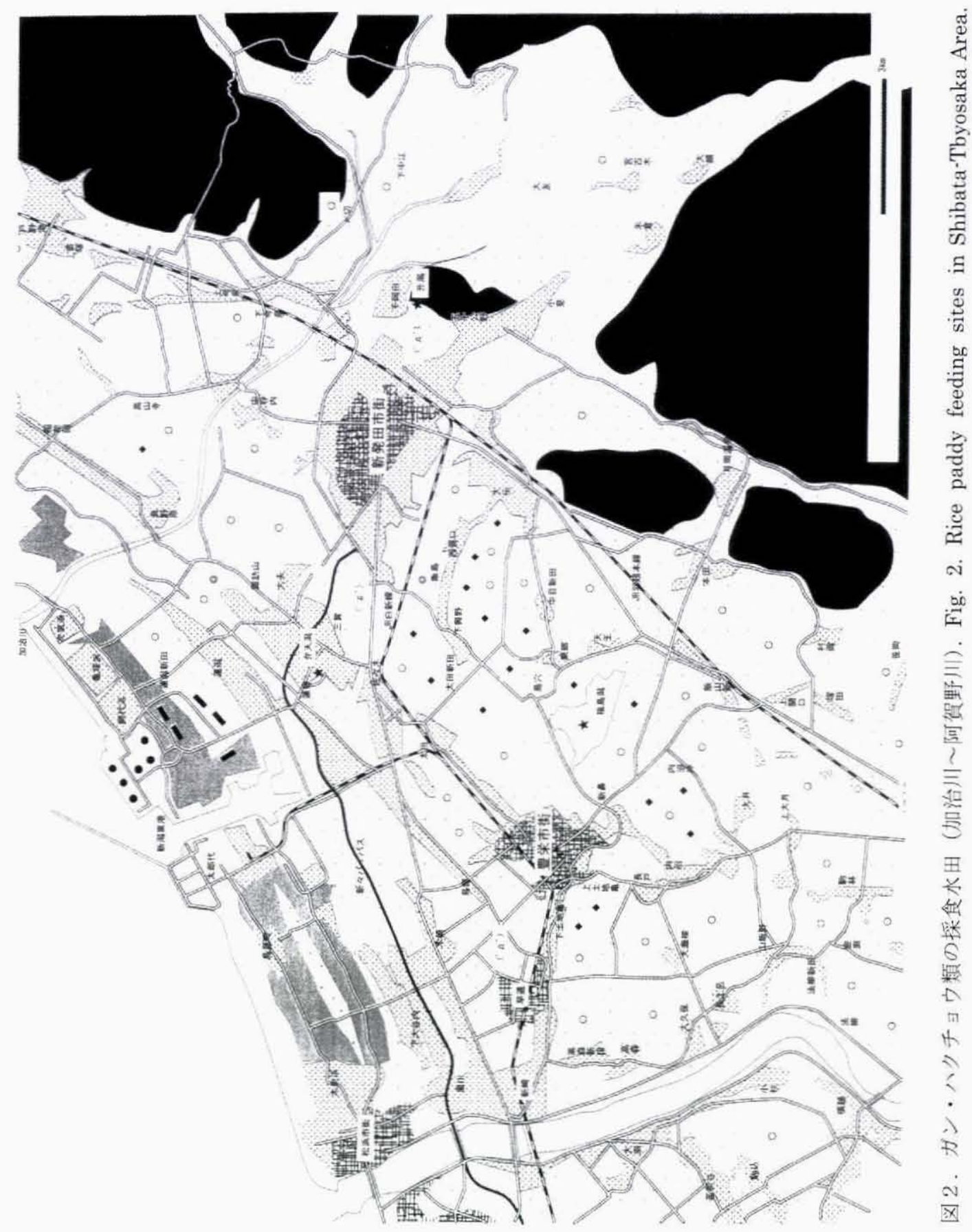




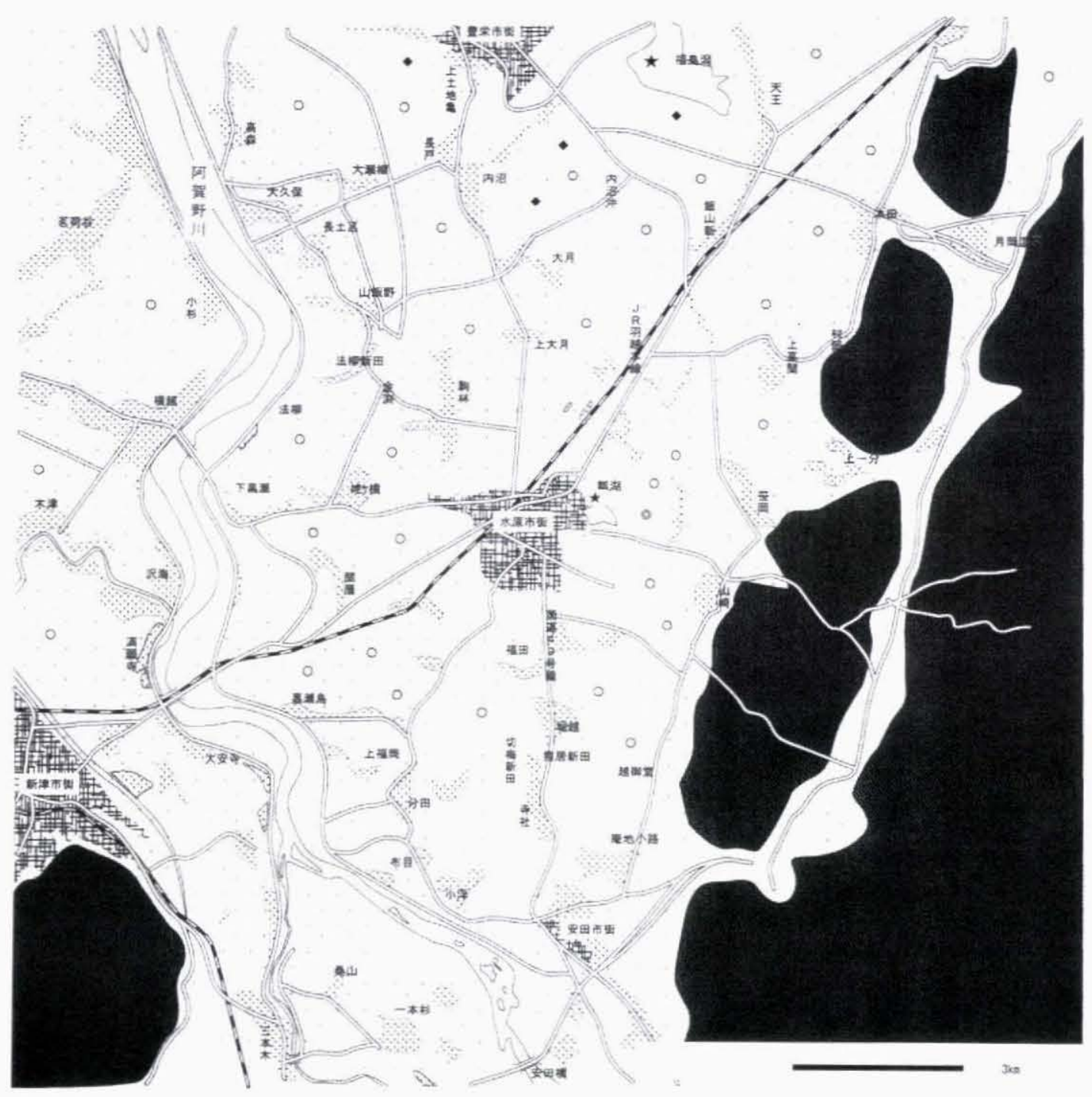

図 3.ガン・ハクチョウ類の採食水田(水原周辺).

Fig. 3. Rice paddy feeding sites in Suibara Area.

なく，福島潟からはより遠い，加治川の対岸である高山寺周辺の水田がよくオオヒシクイに利用され る理由は不明である。諏訪山集落付近の狭い水田では，よくオオハクチョウを見かけた（1994年11月 20 日成鳥 11 羽, 幻鳥 11 羽など).

6) 福島潟周辺（豊栄～豊浦, 図 2 )

コハクチョウ，オオヒシクイの溡である福島潟周辺の地域である. コハクチョウは多くの場所で見 られる。しかし新井郷川の北側には少なく，鳥屋集落周辺と太田集落周辺の水田ではそれぞれ1994年 
12月30日に 1 家族群を確認した。しかし，木崎，早通集落周辺ではガン・ハクチョウ類を見たことはな い. 新新ハイバスより北側には砂丘列が海岸と平行に走り, 砂丘と砂丘の間は水田となっているがこ の付近の水田でもガン・八クチョウ類を観察したことはない，オオヒシクイに関しては，千葉ら（19 92）による報告の通りである。すなわち, 福島潟干拓地（残存する潟の寸ぐ南側）福島渴の寸く北側, すぐ東側, 及び潟の東北側に広がる水田地带（鳥穴集落周辽，佐々木駅周辺，太田新田集落周辺，下 興野集落周辺, 饭島・西䇾口集落周辺, 中の目新田集落周辺), 潟の西側に広がる水田地带（内沿沖 . 内沼・大月集落周辺，上土地亀・下土地亀・長戸集落周辺）である.オオヒシクイが見られるのは， 前記した加治川在岸の水田地带を除けば, 抯である福島潟を中心に, すへてJR白新線と羽越本線の内 側で, 線路や新発田市街を飛び越えていない。また, オオヒシクイは, 福島潟の東南方にあたり距 雄的には他の採食水田と変わらない本田・村葥集落付近の水田などでは全く見られないが,この理由 は不明である。

福島潟にはマガンも渡来するが, 福島潟周辺でみられるマガンは単独群というよりは多くの場合才 オヒシクイ群と行動をともにしており，オオヒシクイとともに見られたので, 図 2 には示していない。 佐々木小学校付近の狭い水田では, オオ八クチョウが見られた（1994年11月27日成鳥10羽, 幼鳥 4 羽 など).

7) 水原周辺（京々瀬〜水原・笹神〜安田，図3）

コハクチョウ最大の拠点である就湖があり、コハクチョウは極めて多い.市街地の北側, すなわち 上大月集落付近や金渕，法柳付近から京ヶ瀬村の中心部，JR羽越線の北側にはどの場所でも観察でき た。 また, 酸湖の北東側, 笹神村から豊浦町にかけても多くの場所で観察できた。水原から安田方面 に向けて国道49号線在南下寸ると, 両側の水田の多くの場所にコハクチョウがいるが, 南限は越御堂: 集落付近であった，安田市街が近くなる寺社集落付近には見られなかった．国道49号と阿賀野川の間 も水田地带が広がっているが, 安田市街地奇りの小浮, 布目集落付近にはコハクチョウは見られず, 熊居新田, 切梅新田, 上福岡集落より北側には多くの場所で見られた. ガン類は全く見られなかった。 飘湖のすぐ東側の水田では，コハクチョウとともにオオ八クチョウも見られた。

8) 五泉周辺（五泉～村松，図4）

この地区は，周囲を山地に囲まれているが，水田も決して狭くない．阿賀野川と早出川に挟まれた 桑山、本杉集落周辺ではガン・ハリチョウ類は観察されなからた (1994年12月30日).JR猿和田駅北 側の四谷新, 南側の五三蔵, 大蔵集落周辺ではガン・ハクチョウ類は見られなかったが, 大須鄉集落 周辺の水田で1家族徉老観察した。(1995年 1 月 4 日) この地区で, 最も水田の面積が広い三軒屋集落 付近では, コハクチョウを常に観察できた。(1994年12月11日約30羽など) また，山に近い青橋集落付 近でも，1995年12月11日に10羽前後を観察した。西四谷から四十九集落にかけても広い水田が展開し ているが，1994年12月11日にはガン・八クチョウ類は観察されなかった．当時，この地区周辺には， コハクチョウの埘の存在はあまり広く知られていなかったが,この地区に近い阿賀野川の安田橋下流 には，既にコハクチョウの時があった（高橋 私信）。

9）烏屋野潟南側（信濃川〜阿賀野川〜小阿賀野川に囲まれた地域，図 5 )

鳥屋野潟は新潟の市街地に近いが, 多くのコハクチョウが腑として利用しており, 鳥屋野潟に近い この地城の水田にもコハクチョウが多い、ほとんどの場所でコハクチョウの群が観察されたが，JR白 新線と信越線, 苔荷谷集落の間にある水田地带では一度もコハクチョウを見たことがなく,この理由 


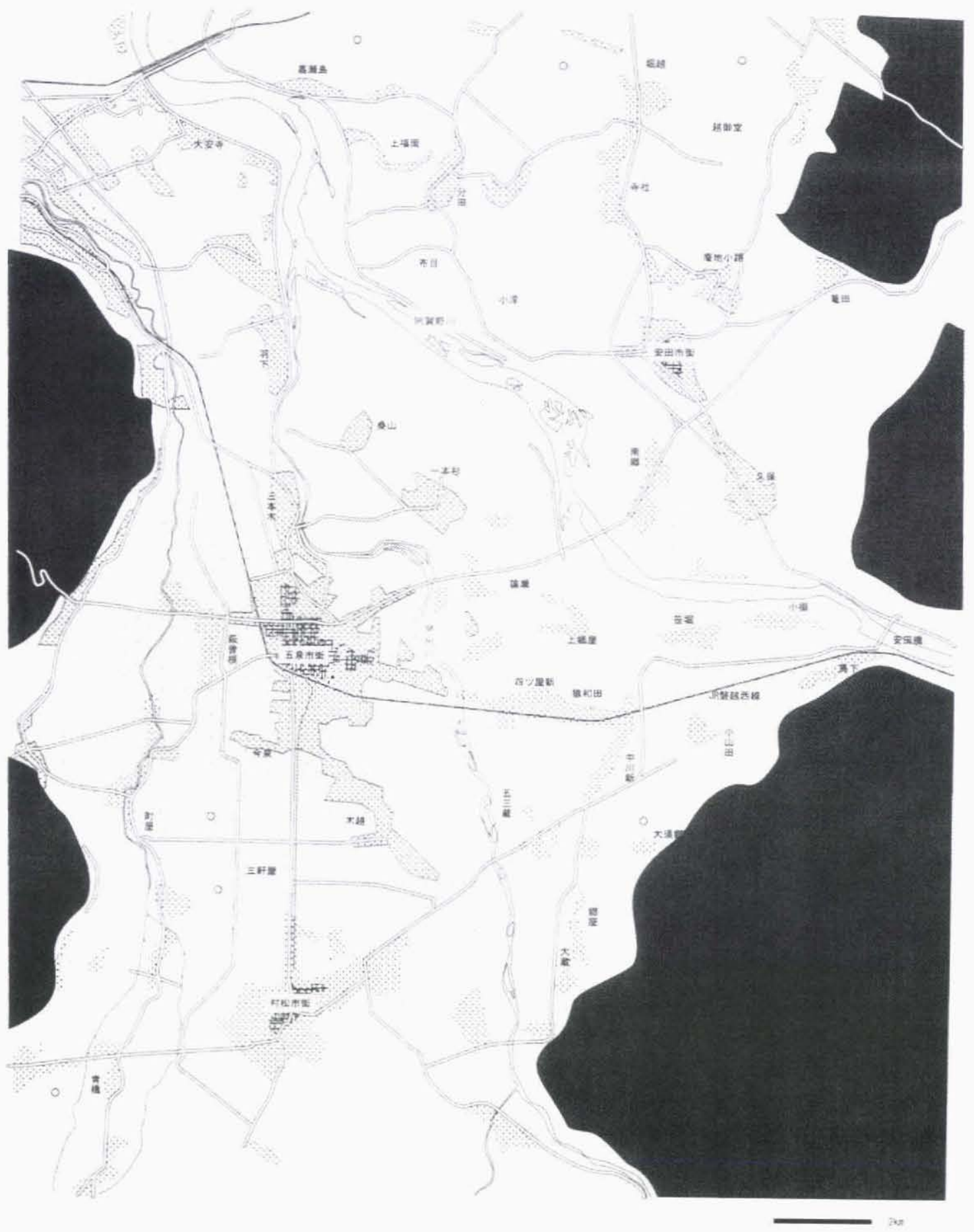

図4.カン・八クチョウ類の採食水田（五泉周辺）。

Fig. 4. Rice paddy feeding sites in Gosen Area.

Bull. JBBA 19, 2006 


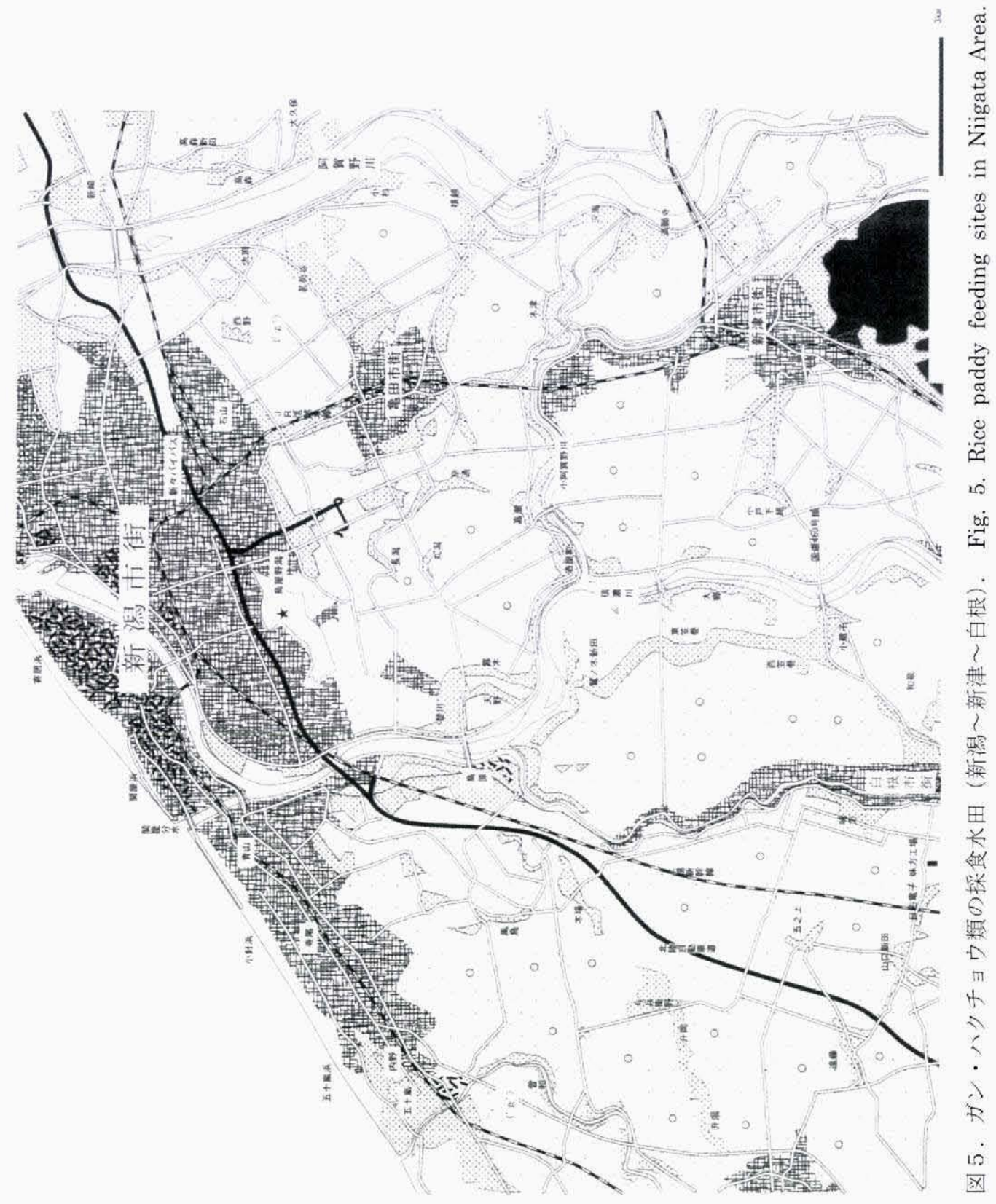

は不明である。

10) 新津・小須戸 ・ 白根付近（図 5 )

この地域もコハクチョウの侍である鳥屋野潟に近く, 多くの場所でコハクチョウが見られた，新津 市では, 市街地の北側, 更に新津と白根を結ぶ国道 460 号線の北側であればコハクチョウは多くの場 
所で見られる。信波川を渡って白根市に入っても同样で, この国道 460 号と信濃川・中之口川に挟ま れた地域であればコハクチョウは多くの場所で見られる。新津市でも，この国道 460 号の南側から小 須戸町にかけての地域では見られなかった。しかし，1回だけ国道 460 号より南の小向集落付近にて19 94年12月 4 日コハクチョウ84羽（成鳥 64, 幼鳥14）を観察した。これより南の地域にはガン・ハクチ ヨウ類は全く見られなかった。信濃川を渡り, 白根市に入っても同椂て, この国道 460 号線の北側に はコハクチョウがどこでも見られ，南側にはこくくすずかか見られなかった，新津市から白根市にか けては、この南市を結ぶ国道 460 号線が, コハクチョウ南下の最終ラインであった.

11) 西蒲原方面（中之口川以西，新潟市流通センターから巻町付近まで，図 6 )

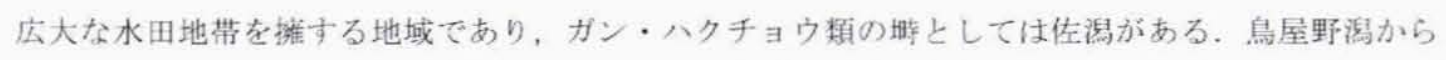

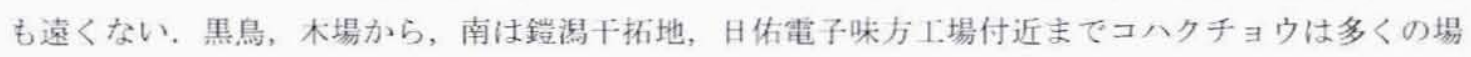
所で見られた。この地区のコハクチョウ南下のラインは, 漆山・茨島集落より北側であり, やはり白 根と巻を結ふ国道 460 線が南下最終ラインとなっていた。 また, 巻町, 西川町から新潟市西部にかけ て国道 116 号線，JR越後線より海よりの地域は1994年12月25日に踏査したが，佐潟の下流部にあたる 藤卷新田，早潟集落付近でコハクチョウの家族群を锶察したほかは，ガン・ハクチョウ類は観察でき なかった。佐潟に近く，面積的にも十分に広いのにもかかわらずコハクチョウが観察されなかった理 由は不明である。また, やはり任潟から近い越後曽根駅の北西側（下山, 川崎, 平野, 中島集落周 辺）でも、コハクチョウは锶察されなからた.

福島潟が冠雪した場合佐潟には多くのオオヒシクイが飛来し，大潟集落付近の水田で多数のオオヒ シクイを見たこともある。しかし，根雪にならない年内は才オヒシクイを見ることは少ない，ただ， 少数ではあるが年内から佐潟に定着しているオオヒシクイも存在する（千葉ら 1993）ので, 今後これ らの個体の採食水田も明らかにする必要がある.

12)三条・燕周辺 (図 7 )

この地区にも，ガン・八クチョウ類の埘は存在しない，前記コハクチョウの南下最終ラインである 国道 460 号線, 寸杂わち新津〜白根, 白根〜巻を結ぷラインの南側から田上町, 加茂市, 三条市, 燕 市, 中之口村, 吉田町にかけては, 広い水田地带はあるものの, ガン・ハクチョウ類がほとんと観察 されない空白地帯となっていた。

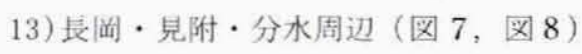

長岡周辺は，近年コハクチョウが増えているという。長埇市内の信濃川にはコハクチョウの時があ り, 朝力には北西方向一飛去する (横沢 2002). しかし, あまり多くの採食水田を記録することがで きなかった。この地域でよく知られているのは, 与板橋下流の信濃川右岸の水田にいるマガン群であ る(渡辺 1985)。このマガン群の持は見つかっていない.この場所では, コハクチョウも必ず镜察さ れる.これ以外の場所では, 信濃川左岸の河根川町集落付近で, 1994年12月 4 日にコハクチョウ9 羽

(成鳥 7 , 幼鳥 2) を, 同じく信濃川左岸の万善寺集落付近の水田で1995年 1 月 3 日にコハクチョウ 約20羽を観察した。丘陵を挟んで和島村の島崎川沿いに広い水田地带が広がっているが, ガン・八ク チョウ類は全く観察されなかった。また，与板町周辺や見附市，栄町周辺でもガン・八クチョウ類を 観察することができなかった.しかし，栄町のJR帯織駅付近の水田にて1994年12月29日にコハクチョ ウ 120 羽前後の群が観察されたと渡辺央氏より連絡を受け, その後筆者も確認した。 また，長岡市の 東部, 小曽根, 亀貝集落より東側にも広大な水田地鱼が広がっているが,この場所でもコハクチョウ 


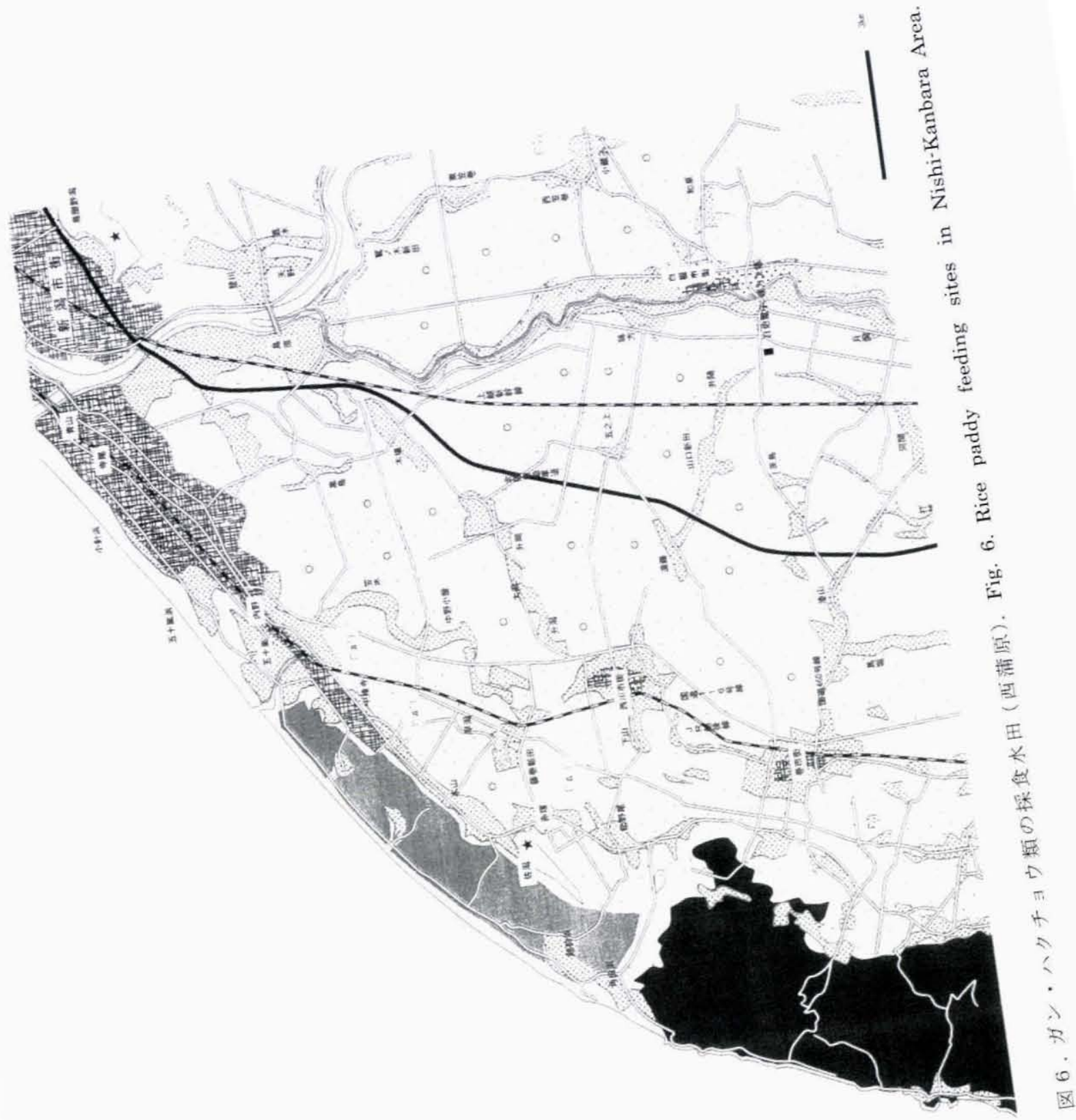

日本鳥粨標識協会誌 19,2006 


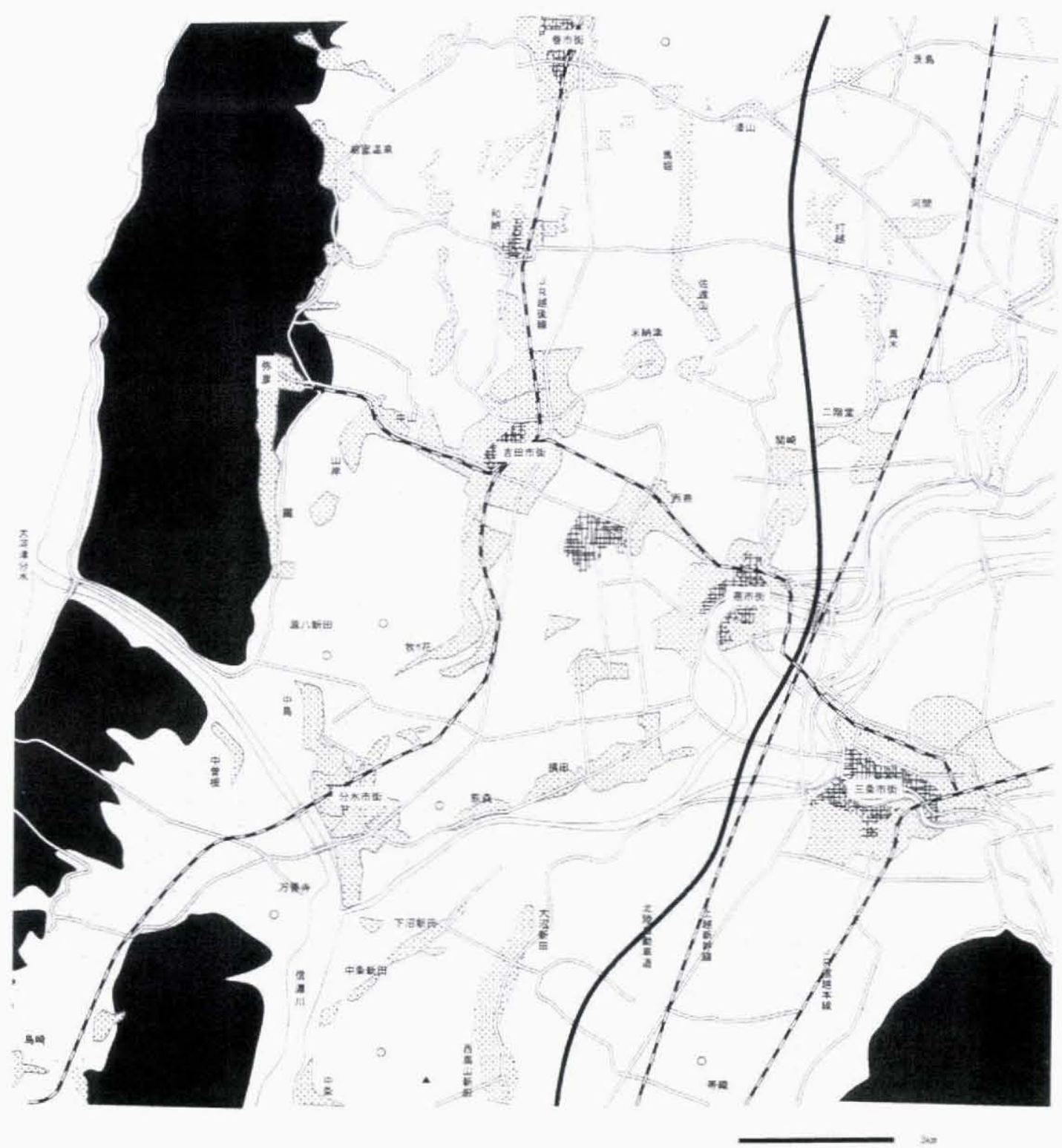

図 7.ガン・八クチョウ類の採食水田（吉田〜燕〜三条）。

Fig. 7. Rice paddy feeding sites in Tsubane-Sanjo Area. 


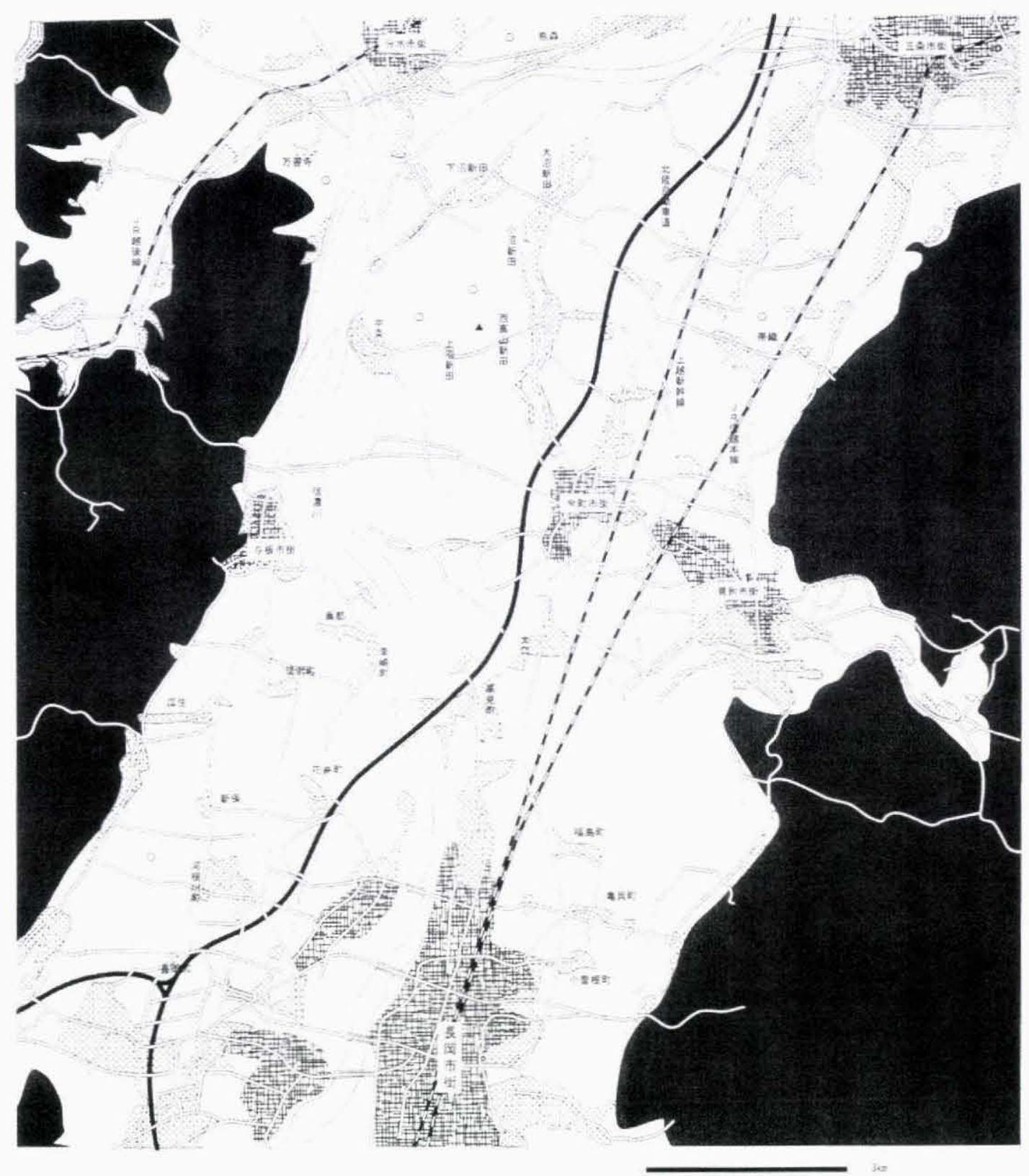

図 8.ガン・八クチョウ類の採食水田 (中之島〜長岡).

Fig. 8. Rice paddy feeding sites in Nagaoka Area.

は観察されなかった。中之島町大口周辺は八ス田の面積が広く, 積雪時にオオ八クチョウとコハクチ ヨウの飛来を観察したことがあるが，常時見られるものではなかった，長岡より山側は，例えば小千 
谷市ではコハクチョウの渡来は少ない, という記録（中山 1985）があったため, 調査していない.

マガン渡来地より信濃川を渡り, 分水町にはいるとコハクチョウの採食水田がある。熊森集落北側 の水田地带では, 1994年12月11日には5 羽が, 1995年1月3日には14羽が飛翔していた。降りている ところは観察していないが, この場所も採食水田である可能性が高い. また, 弥彦村に近い源八新田 集落付近で1995年 1 月 3 日に 2 群 100 羽以上老観察した。この 2 力所より北では, 例の巻〜白根線ま で全く観察されない地域が続く，分水周辺のコハクチョウは，どの侍から飛来しているのか不明であ った.

\section{2. 種ごとの採食水田の分布（図 9)}

マガンに関しては, 中之島町の信濃川右岸の水田と, 福島潟周辺水田で見られただけであり, 従米 の知見を裏付けた結果となった。

オオヒシクイに関しては，千葉ら（1993）に示されたとおう，福島潟周辺の各所で観察されたほか， 従来全く知られていなかった加治川東岸の採食水田を発見することができた.

オオ八クチョウは, 水田で見られることが少なかったが, 新発田周辺で 2 ヶ所, 漂湖東側で 1 ケ所 钼察された。

コハクチョウの採食水田は, 越後平野に広く分布していた。特に, 加治川西岸から新発田, 豊栄, 水原, 新潟市街南側の鳥屋野潟から白根, 西川, 巻にかけてはほとんどの水田地带で連続的に見られ た.この範囲内でも，一部にコハクチョウが利用しない水田があった。例をあげれば新発田市の升潟 の前面, 新発田市西部の山賀付近, 新潟市東部の茗荷谷周辺, 西川町の越後兽根駅の北西側（下山, 川崎, 平野, 中島集落周辺) などである. 一方, 荒川以北や加治川不岸, 五泉, 分水や長岡方面では, 断続的にコハクチョウの採食水田が仔在した，付近に埘のない北蒲原地区の中条周辺，三条・燕周辺 などは，広い水田がありながらもコハクチョウの採食群は全く見られなかった。

\section{考 察}

本研究により，1992１995年当時の，越後平野におうりるガン・八クチョウ類の採食水田の分布状況 が明らかになった。マガン, オオヒシクイ, オオハクチョウの採食水田は地域的にごく限られていた. コハクチョウの採食水田は, 広い範囲に連続的に分布していたが, 全く見られない地域や断続的にし か見られない地域も広かった。連続的に見られる地域でも，一部にコハクチョウに利用されない水田 もあった.

ガン・八クチョウ類が採食水田を選ぶ第一の条件として, 時からの距離が考えられる。嶋田(2003) は, 宮城県伊豆沼周辺で越冬するマガンについて, その多く $(68.8 \%)$ は塒から $6 \mathrm{~km}$ 末満の距離の 水田で記録され，そのほとんど $(93.6 \%)$ は, 侍から $12 \mathrm{~km}$ 以内の水田で観察され，また塒からマガン が最初に利用した水田までの平均距離は $5.2 \pm 0.6 \mathrm{~km}$ であった, としている. 本調査でも, オオヒシ クイの採食水田は通常福島潟の周辺に限って認められ, コハクチョウも, 付近に煋のない中条や三 条・燕周辺の水田では全く認められなかった。

越後平野の水田で採食するコハクチョウは，塒が複数存在しているため，どの時から飛来したもの 


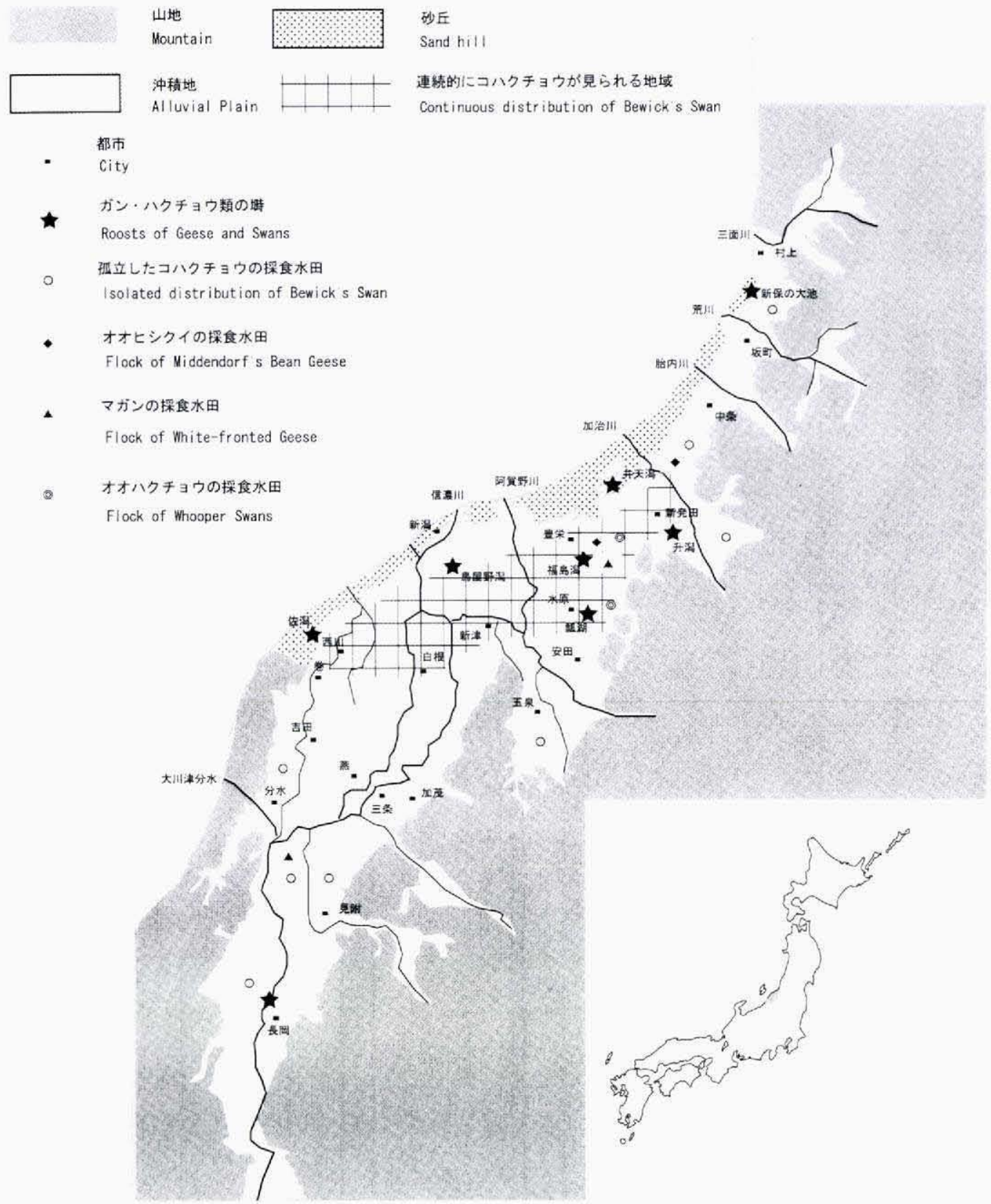

図 9. 越後平野一带におけるガン・八クチョウ類の採食水田の分布.

Fig. 9. Ditribution of geese and swans rice paddy feeding sites on Echigo Plain. 
かわかりにくく，侍と採食水田の閒の距離を推定しにくい.しかし，最も距離的に近いと考えられる 侍からの距離を計測すると, 遠い場合でも約 $10 \mathrm{~km}$ と推測された。積雪のない時期のオオヒシクイで, 侍から採食水田までの距離を考えると, 唯一の時である福島潟から約 $6 \mathrm{~km}$ 以内である.しかし, 本曲 種の採食水田は，福島潟から同心円状に分布しているわけではなく，加治川右岸に発見された本亚種 の採食水田は福岛潟から $10 \mathrm{~km}$ 以上の距離があった。

ガン・八クチョウ類には，時からの距雖だけでなく，採食水田を選ぶ何らかの基準があるようであ る.コハクチョウでは, 前述した 4 力所の例のように, 塒からの距離は採食地として利用されている 周辺水田と変わらないにもかかわらず，利用されていない場所があった，オオヒシクイでも，例えば 本田・村岡集落付近の水田などは，本亜種がよく利用する西䇾口，飯島付近の水田よりも侍である福 島潟から近いにもかかわらず全く利用されなかった。越後平野の水田地带は，ほとんどの場所で围場 整備は終了し，水位，底質など，固場の環境自体にはそれほど差があるものとは考えられない、にも かかわらず利用される水田と利用されない水田がある，ということは，侍からの距離という理由以外 に，ガン・八クチョウ類が採食水田を選択寸る何かの基準があることを示している．また，前記した， オオヒシクイが利用しない本田・村岡集落付近の水田地帯は, コハクチョウは多く見られる場所であ る.このことは, 種によって, 採食水田の選択基淮に違いがあること寺している.

今後は, 各種の, 更に詳細な水田利用の状況を調查し, それぞれの種の, 水田の選択基準を明らか にしてゆく必要がある.

\section{謝 辞}

本調査を行なうにあたり，多くの皆さまのお世話になりました．特に，コハクチョウの採食水田や 埘孝教えていただいた新津市理科教育センター (当時) の石部久氏, 三条市の北沢秀機氏, 日本白鳥 の会の木田清氏, 西蒲原郡卷町の佐藤吟一氏, 株式会社サザンウィンドの高橋正良氏, 長岡市立科学 博物館（当時）の渡辺央氏に厚く御礼申し上げます.

\section{摘 要}

1992年から1995年にかけ, 越後平野一帯におけるガン・八クチョウ類の採食水田の分布を調查した。 マガン, オオヒシクイ，オオ八クチョウの採食水田は，地域的に限られていた。 コハクチョウの採食 水田は, 広い範囲に連続的に分布していたが, 全く見られない地域や断続的にしか見られない地域も 広からた，連続的に見られる地域内にも，コハクチョウに利用されない水田が少数あった。

ガン・八クチョウ類が採食水田を選択する条件として，第一に時からの距離が考えられたが，それ 以外にも何らかの選択基淮があるものと考えられた。

\section{SUMMARY}

The distribution of rice paddies utilized as feeding sites by wintering geese and swans was 
studied. The research was conducted on the Echigo Plain over a four year period from 1992 through 1995, and focused on four species White-fronted Goose Anser albifrons, Middendorf's bean Goose A. fabalis, Whooper Swan Cygnus cygnus and Bewick's Swan C. columbianus. The Echigo Plain, located in Niigata Prefecture along the Japan Sea side of central Honshu (Fig. 9, bottom right), is one of Japan's major alluvial floodplains, formed by the Shinano and Agano Rivers. The plain is an important waterfowl wintering region, and previous research conducted by the Ministry of the Environment had analyzed the distribution of lakes, marshes and lagoons used by various species. Observations, however, indicate that rice paddies also serve as feeding sites. The surveys in this research covered all the rice paddies on the Echigo Plain, and were conducted in early winter (Nov. to Jan.) to eliminate the effects of deep snow cover and the onset of spring migration. The Echigo Plain was divided into thirteen regions, the results for which are mapped in Fig. 1 through 8. In addition, the overall pattern was displayed on a map covering the entire Echigo Plain (Fig. 9). The results showed that feeding sites of White-fronted Goose, Middendorf's bean Goose and Whooper Swans were restricted to particulars areas. The sites for Bewick's Swan were distributing continuously over some areas, but totally absent from others. These results confirm earlier studies that the distribution of feeding sites and roosts are interrelated. The sites used by Middendorf's bean Goose, however, were about $10 \mathrm{~km}$ from the nearest roost, even though there were potential feeding sites much closer. Also, although Bewick's swans utilize several roosting sites on the Echigo Plain, and the research could not determine from which of these sites the geese feeding at any area had come, distances between feeding sites and nearest roost were up to $10 \mathrm{~km}$. These observations indicate that some factor other than distance from roost is also at least partially responsible for choice of feeding site. In addition, some feeding sites ignored by Middendorf's bean Goose were utilized by Bewick's Swan, suggesting that the factors used in choosing feeding sites may vary among species.

\section{引用文献}

千葉晃 1985. 新潟県におけるガンカモ科鳥類の渡来・生息状況. 野鳥新潟 $(60): 2-3$.

千葉晃・高辻洋・山本明・本閒隆平 1993. 新潟県に飛来するヒシクイとその越冬生活. 第六次鳥獣保 護事業計画鳥獣保護対策調查報告書 I . 新潟県, 新舄市.

本田清 2001. 白鳥の湖. 新潟日報事業社, 新潟市.

中山正則 1985. 小千谷の鳥類. 小千谷市立理科教育センタ一理科研究集録 19:55-72.

新潟県野鳥愛護会研究部 1993. 平成 4年度ガン・カモ科鳥類の生息状況調査. 野鳥新潟 (84):10-11.

新潟県野鳥愛護会研究部 1994. 平成 5年度ガン・カモ科鳥類の生息状況調査. 野鳥新潟 (88):10-11.

新潟県野鳥愛護会研究部 1995. 平成 6年度ガン・カモ科鳥類の生息状況調查. 野鳥新潟 (92):8-9.

坂井陽一 1991. 新潟市史. 資料編12 (自然). 新潟市, 新潟市.

嶋田哲郎 2003. 伊正沼・内沼における越冬期のマガンの採食場所の分布. 日鳥学誌 52:32-34. 
渡辺朝一 2003. 越後平野の水田におけるコハクチョウの採食個体割合の経時変化. 日本の白鳥 $27: 2-$ 8.

渡辺弘雄 1985. 三島郡与板町周辺のマガンについて. 野鳥新潟 (60) :4-5.

横沢文子 2002. 信濃川中流域 (長岡市)に形成される八クチョウのねぐらについて. 野鳥新潟 (118) $: 3$.

渡辺朝一

テ310-0032 水戸市元山町 2-2-33-202

Tomokazu Watanabe

2-2-33-202 Motoyamacho, Mito-shi, Ibaraki 310-0032, Japan

付表 1.1993 1995年の越後平野の池沼におけるガン・八クチョウ類の個体数.

Appendix 1. Number of geese and swans observed at selected roosting sites on the Echigo Plain.

\begin{tabular}{|c|c|c|c|c|c|}
\hline $\begin{array}{l}\text { 場所 } \\
\text { Place }\end{array}$ & 年 & $\begin{array}{c}\text { マガン } \\
\text { Anser albifrons }\end{array}$ & $\begin{array}{l}\text { ヒシクイ } \\
\text { A. fabalis }\end{array}$ & $\begin{array}{l}\text { オオハクチョウ } \\
\text { Cygnus cygnus }\end{array}$ & $\begin{array}{c}\text { コハクチョウ } \\
\text { C. columbianus }\end{array}$ \\
\hline 新保の大池 & 1993 & 0 & 0 & 190 & 16 \\
\hline \multirow[t]{2}{*}{ Shinpo Pond } & 1994 & 0 & 0 & 346 & 10 \\
\hline & 1995 & 0 & 0 & 140 & 335 \\
\hline 荒川河口 & 1993 & 0 & 0 & 17 & 128 \\
\hline \multirow[t]{2}{*}{ Arakawa River mouth } & 1994 & 0 & 0 & 0 & 0 \\
\hline & 1995 & 0 & 0 & 0 & 0 \\
\hline 弁天渴 & 1993 & 0 & 0 & 243 & 213 \\
\hline \multirow[t]{2}{*}{ Lake Bentengata } & 1994 & 0 & 0 & 296 & 56 \\
\hline & 1995 & 0 & 0 & 162 & 16 \\
\hline 升潟 & 1993 & 0 & 0 & 53 & 353 \\
\hline \multirow[t]{2}{*}{ Lake Masugata } & 1994 & 0 & 0 & 38 & 342 \\
\hline & 1995 & 0 & 0 & 63 & 274 \\
\hline 紅湖 & 1993 & 0 & 0 & 282 & 2,866 \\
\hline \multirow[t]{2}{*}{ Lake Hyoko } & 1994 & 0 & 0 & 227 & 5,523 \\
\hline & 1995 & 1 & 25 & 228 & 3,108 \\
\hline
\end{tabular}




\begin{tabular}{|c|c|c|c|c|c|}
\hline 福島潟 & 1993 & 140 & 1,720 & 0 & 1,394 \\
\hline \multirow[t]{2}{*}{ Lake Fukushimagata } & 1994 & 70 & 2,280 & 4 & 1,313 \\
\hline & 1995 & 2 & 330 & 9 & 1,210 \\
\hline 阿賀野川 & 1993 & 0 & 0 & 0 & 0 \\
\hline \multirow[t]{2}{*}{ Agano River } & 1994 & 0 & 0 & 0 & 6 \\
\hline & 1995 & 0 & 0 & 0 & 0 \\
\hline 信濃川新潟 & 1993 & 0 & 0 & 0 & 0 \\
\hline 八千代橋一千歳大橋 & 1994 & 0 & 0 & 0 & 0 \\
\hline Shinano River Niigata Area & 1995 & 0 & 0 & 2 & 118 \\
\hline 鳥屋野潟 & 1993 & 0 & 21 & 31 & 706 \\
\hline \multirow[t]{2}{*}{ Lake Toyanogata } & 1994 & 0 & 8 & 26 & 620 \\
\hline & 1995 & 0 & 1,284 & 14 & 722 \\
\hline 佐潟 & 1993 & 0 & 151 & 95 & 3,558 \\
\hline \multirow[t]{2}{*}{ Lake Sakata } & 1994 & 0 & 10 & 109 & 3,575 \\
\hline & 1995 & 16 & 1,514 & 163 & 2,062 \\
\hline 信濃川分水 & 1993 & 323 & 0 & 21 & 0 \\
\hline 与板橋一分水塇 & 1994 & 569 & 0 & 0 & 13 \\
\hline Shinano River Bunsui Area & 1995 & 166 & 0 & 0 & 0 \\
\hline 信濃川越路 & 1993 & 0 & 0 & 11 & 125 \\
\hline 蔵王橋一军ケ島 & 1994 & 0 & 0 & 0 & 471 \\
\hline Shinano River Koshiji Area & 1995 & 47 & 0 & 0 & 0 \\
\hline 計 & 1993 & 463 & 1,892 & 943 & 9,359 \\
\hline \multirow[t]{2}{*}{ Total } & 1994 & 639 & 2,298 & 1,046 & 11,929 \\
\hline & 1995 & 232 & 3,153 & 781 & 7,845 \\
\hline
\end{tabular}

本表は以下の3文献に示された調査結果より引用して作表したものである。新潟県野鳥愛護会研究 部 1993. 平成4年度カンン・カモ科鳥類の生息状況調查. 野鳥新潟 (84): 10-11. 新潟県野鳥爱護会研 究部 1994. 平成5年度ガン・カモ科鳥類の生息状況調查. 野鳥新潟 (88):10-11. 新潟断野鳥愛護会 研究部 1995。平成6年度ガン・カモ科鳥頪の生息状況调查. 野鳥新潟 (92):8-9. 